\title{
Blood lead levels of children before and after introduction of unleaded petrol
}

\author{
Manouri P Senanayake ${ }^{1}$, MDA Rodrigo ${ }^{2}$ and R Malkanthi ${ }^{3}$
}

\section{Introduction}

Nations around the world have banned lead in petrol [1]. The primary reason for removing lead additives from petrol is its adverse effect on human health. In response to evidence that blood lead concentrations approaching toxic levels in children and traffic policemen in Sri Lanka, tetraethyl lead was removed from petrol in the year 2002. Following this change a reduction in roadside atmospheric lead by $81.5 \%, 82 \%$ and $84 \%$ has been demonstrated at three locations in Colombo [2]. We report on blood lead levels of children before and after the discontinuation of leaded petrol.

\section{Method}

A cohort of children living near a traffic congested junction in Colombo had their blood lead levels determined one year after the change to unleaded petrol and were compared with levels of a comparable group studied when leaded petrol was still in use [3]. These two community based, cross-sectional descriptive studies were conducted in 1998 and 2003. Forty randomly selected, apparently healthy children between the age of one and fifteen years, who had been domiciled since birth within a radius of $0.5 \mathrm{~km}$ from the Borella junction comprised the 2003 study sample. Following ethical approval and informed consent, $2 \mathrm{ml}$ of venous blood was collected into lead free containers from each child. Each blood sample was analysed for lead at the Occupational Hygiene and Safety Division of the Labour Department in Colombo by atomic absorption spectrometry.

The results were compared with blood lead levels of a cohort of 50 children investigated in 1998 [3]. The two cohorts were of the same socioeconomic background and locality, and of similar age and sex distribution.

In both studies lead was present in all samples analysed. In the 2003 study, the lead levels ranged from $1.67 \mu \mathrm{g} / \mathrm{dL}$ to $9.7 \mu \mathrm{g} / \mathrm{dL}$ and none of the samples contained lead levels above $10 \mu \mathrm{g} / \mathrm{dL}$. This differed from the previous study of 1998 when $6 \%$ of the children had levels at or above $10 \mu \mathrm{g} / \mathrm{dL}$. The mean blood value reported in 1998 was $5.21 \mu \mathrm{g} / \mathrm{dL}(\mathrm{SD} \pm 1.78 \mu \mathrm{g} / \mathrm{dL})$ and in 2003 , $4.33 \mu \mathrm{g} / \mathrm{dL}(\mathrm{SD} \pm 1.81 \mu \mathrm{g} / \mathrm{dL})$. When lead levels of the total blood samples of the two studies were compared, there was a statistically significant reduction (Table 1). In both studies the levels were higher in boys. A notable

${ }^{1}$ Professor in Paediatrics, ${ }^{2}$ Demonstrator, Department of Paediatrics, Faculty of Medicine, University of Colombo; ${ }^{3}$ Senior Scientist, Occupational Hygiene and Safety Division, Department of Labour, Colombo, Sri Lanka.

Correspondence: MPS, e-mail: <manouri_senanayake@yahoo.co.uk> (Competing interests: none declared). Received 14 October 2003 and accepted 30 October 2003. 
difference was that the blood lead concentrations increased with age in the 1998 study, whereas in 2003 the levels were higher in the younger age groups.

Table 1. Blood lead levels before (in 1998) and after the change to unleaded petrol (in 2003)

\begin{tabular}{|c|c|c|c|c|}
\hline \multirow{3}{*}{$\begin{array}{l}\text { Age } \\
\text { (years) } \\
\text { Below } 5\end{array}$} & \multicolumn{3}{|c|}{ Blood lead level $(\mu g / d L)$} & \multirow{3}{*}{$\begin{array}{l}p \text { value } \\
p>0.05\end{array}$} \\
\hline & 1998 & \multicolumn{2}{|c|}{2003} & \\
\hline & $4.3 \pm 1.9 \quad(n=25)$ & $4.8 \pm 1.7$ & $(n=11)$ & \\
\hline $6-10$ & $5.5 \pm 1.3 \quad(n=12)$ & $4.7 \pm 2.0$ & $(n=14)$ & $\mathrm{P}>0.05$ \\
\hline Above 10 & $6.7 \pm 1.8 \quad(n=13)$ & $3.8 \pm 1.7$ & $(n=14)$ & $\mathrm{P}<0.05$ \\
\hline Total & $5.2 \pm 1.8 \quad(\mathrm{n}=50)$ & $4.4 \pm 1.8$ & $(n=39)$ & $\mathrm{P}<0.05$ \\
\hline Girls & $4.9 \pm 1.4 \quad(n=25)$ & $3.9 \pm 1.0$ & $(n=13)$ & \\
\hline Boys & $6.1 \pm 1.7 \quad(n=25)$ & $4.9 \pm 1.9$ & $(n=26)$ & \\
\hline
\end{tabular}

\section{Discussion}

Leaded petrol is considered a major cause of lead exposure worldwide. More than 50 nations have abandoned the use of lead in petrol since 1976, and more are planning such action in the next few years [1]. Blood lead levels of children in the USA fell dramatically after discontinuation of lead in petrol; $4 \%$ of children between 6 months and 5 years of age had lead levels over $30 \mu \mathrm{g} / \mathrm{dL}$ in 1975 , and by 1994 only $7 \%$ had more than $10 \mu \mathrm{g} / \mathrm{dL}$; only $0.1 \%$ had levels in excess of $20 \mu \mathrm{g} / \mathrm{dL}$ [4].

Lead has a half-life of 25 days in the blood stream and 50 days in soft tissue. Twelve months after the discontinuation of leaded petrol we found a statistically significant reduction in blood lead. Blood lead level that indicates the need for environmental intervention is $10 \mu \mathrm{g} / \mathrm{dL}$ [5]. In the 1998 study $6 \%$ of children had blood lead levels above $10 \mu \mathrm{g} / \mathrm{dL}$ whereas in the 2003 study none had levels above $10 \mu \mathrm{g} / \mathrm{dL}$, the highest blood level being $9.67 \mu \mathrm{g} / \mathrm{dL}$.

We did not find a significant decrease in blood lead levels in the younger age groups. Significant reductions had occurred only in older children. The probable explanation for this is that lead is a stable metal that accumulates in the environment in different forms, and remains for long periods in the soil, entering vegetation, settling on household dust, food, toys and other objects. Increased hand-to-mouth activities of preschool children encourages the entry of particulate lead orally. Their gut absorption of lead is four times higher than adults and this is further enhanced in deficiency states of iron and protein. Our finding that lead persisted in the very young, the population group that is particularly vulnerable to cognitive effects, shows that the eradication of lead from the environment is slow. This is supported by the conclusion of the study on atmospheric lead levels in Colombo which notes that "changing trends with respect to particulate lead is less than that of the total lead levels"[2].

We concluded that one year after the change to lead free petrol the overall risk of environmental lead exposure is reduced, but the exposure risk to children below the age of 10 years remains.

\section{References}

1. Landrigand PJ. The worldwide problem of lead in petrol. Editorial: WHO Bulletin 2002; 80: 10.

2. Changing atmospheric lead levels in Colombo with discontinuation of leaded petrol in Sri Lanka. A report by Environmental Division of National Building Research Organization, Colombo, Sri Lanka, February 2003.

3. Amaratunge S, Sumanasena SP, Hubert HDM, Senanayake MP. Blood lead levels of children living near Borella junction. Ceylon Medical Journal 2001; 46: 111

4. Piomelli S. Childhood lead poisoning. Pediatric Clinics of North America 2002; 49: 1285-304.

5. Centers for Disease Control, Preventing lead poisoning in young children. A statement by the Centers for Disease Control, Atlanta, GA, US Department of Health and Health Services, October 1991. 